\title{
Dlaczego warto inwestować w humanistykę?
}

humanistyką i humanistami wiąże się wiele mitów oraz legend miejskich. Rozpoczynając od definiowania humanisty jako kogoś, kto nie rozumie matematyki, kończąc na micie biednego intelektualisty, który jedynie w wyciągniętym swetrze i z puszką konserwy w dłoni może prawdziwie pracować.

Na początku ubiegłego wieku nauka zachłysnęła się na powrót fizyką i możliwością matematycznego opisu całej ludzkiej wiedzy. Na szczęście od wielu dekad jest już inaczej, a na najlepszych uczelniach technicznych są całe wydziały nauk humanistycznych i społecznych (jeden z najlepszych wydziałów posiada słynny amerykański MIT). Warto podkreślić, że humanistyka w XXI wieku to paliwo wielu koncepcji naukowych, jak również zaawansowane badania w ramach humanistyki cyfrowej. Jednakże — i to jest najważniejsze — to wciąż kontynuacja trwającej kilka tysięcy lat praktyki bycia obywatelem.

Dlaczego zatem warto inwestować w humanistykę? Krótka odpowiedź brzmi: Chociażby dlatego, że na to pytanie wciąż musimy odpowiadać. A teraz dłuższa: nie to jest problemem, że decydenci i politycy, którzy najczęściej poruszają tę kwestię, nie znają odpowiedzi. Wyzwaniem jest fakt, że pytanie to w ogóle jest zadawane i że — tak wielu mądrych ludzi — stara się na nie odpowiedzieć.

A to zagadnienie jest podchwytliwe. Okazuje się bowiem, że pytający chcą nas wciągnać w swoja grę, w której nie mamy szans wygrać. Takie sytuacje znamy: zapewne znaja państwo tę anegdotę, w której pracownik pyta swojego dyrektora, czy to prawda, że przestał bić żonę? Nie ważne, jak dyrektor odpowiedziałby, jeśli odpowie — wpada w sidła.

Humaniści na pytanie o to, dlaczego warto inwestować w humanistykę, odpowiadają najczęściej: to nas ubogaca, rozwija krytyczne myślenie, pozwala budować swoje kompetencje społeczne. Tylko że najczęściej nie takiej odpowiedzi się oczekuje, poruszając tę kwestię. Oczekuje się, aby ktoś w końcu powiedział: bo jest praca dla humanistów, bo wzrośnie PKB, bo przemysł i gospodarka tego potrzebuje. To właśnie pokazuje przewrotność tego zagadnienia. 
Jednakże mimo tych zastrzeżeń, wciąż — niczym Syzyf — musimy na to pytanie odpowiadać ze względu na nasz własny obywatelski interes. Bo właśnie wszystko rozbija się o obywatela i jego kompetencje.

\section{Obywatel. Punkt wyjścia i dojścia}

Politycy zbyt często mówią nam, że humanistyka nie ma znaczenia i nie ma sensu jej finansować. Ironią losu jest to, że ci politycy i decydenci, którzy najczęściej mają wykształcenie humanistyczne i społeczne, uważają, że nie warto inwestować w humanistykę. Najczęściej ci sami myślą o nas tylko jako o pracownikach i konsumentach, a nie o obywatelach czy jednostkach. Mówią: nie potrzebujemy humanistyki, wszystko czego potrzebujemy to pracownicy na rynku pracy. Pracownicy, którzy wzbogacą ich, lecz nie ubogacą nas.

Dopóki jako społeczeństwo nie będziemy się zastanawiać, czym jest — jak mówili starożytni Grecy — „dobre życie”, dopóty nie dziwmy się, że mamy takich polityków i rządzących, na jakich zasługujemy. Humanistyka czyni nas lepszymi obywatelami, co, patrząc na historię, stało u podstaw sukcesu greckich poleis. Politycy pytają: do czego w ogóle jest ta humanistyka potrzebna, komu się przydaje, i dlaczego warto inwestować w humanistykę? Otóż humanistyka jest dla nas jako jednostek i obywateli w społeczeństwie. Po prostu. To bardzo prosta i niezwykle złożona odpowiedź zarazem.

Kiedy przestajemy być obywatelami i zaczynamy myśleć o sobie tylko jako o konsumentach, zaprzepaszczamy tysiące lat rozwoju ludzkiej cywilizacji. Jak mamy podtrzymać naszą kulturę, jeśli nie rozumiemy, jak ona działa? Jak mamy chronić swoje prawa, jeśli nie potrafimy zrozumieć konstytucji?

\section{Kompetencje obywatela}

Nie wystarczy być obywatelem. Trzeba być obywatelem, który potrafi dokonywać trafnych wyborów. Do tego potrzebujemy natomiast kompetencji miękkich, kompetencji komunikacyjnych i społecznych.

Dzisiaj żyjemy w kulturze bardziej zdefiniowanej przez obrazki i historie niż to do tej pory było. Dlatego tak istotne jest posiadanie odpowiednich kompetencji, które zabezpieczą nas przed wpływem manipulacji, prowokacji czy — modnej ostatnio — postprawdy.

Dlatego musimy rozwijać umiejętność komunikacji — nikt się z tym nie rodzi, a zwykłe rozmowy z przyjaciółmi i rodziną nie nauczą nas precyzyjnego posługiwania się językiem, co pozwoli nam prowadzić zaawansowane negocjacje czy naprawiać nasz skomplikowany świat.

Ludzie są zatrudniani ze względu na swoje doświadczenie zawodowe, a zwalniani najczęściej ze względu na brak kompetencji miękkich. Humanistyka pozwala rozwijać krytyczne myślenie, konstruowanie klarownych komunikatów czy też przygotowuje do zaangażowanego i bogatego życia, przekracza zatem to, co określa się mianem satysfakcji z pracy i wynagrodzenia.

Humanistyka to nie tylko filologia, historia czy filozofia. To również socjologia, muzykologia czy nauki o polityce publicznej. Kiedy pytamy o humanistykę, chodzi nam najczęściej o tzw. nauki miękkie, w odróżnieniu od nauk twardych, takich jak fizyka, chemia czy biologia. Owe miękkie nauki są specyficzne, ponieważ przedmiotem ich studiów jest sam człowiek, który nieustannie wybiera. A tam, gdzie mamy różnie umotywowane wybory, nie można użyć po prostu praw fizyki, by zrozumieć ludzi i konsekwencji ich działań. 
Oznacza to, że inwestowanie w humanistykę pozwala ludziom stawać się lepszymi obywatelami, którzy dokonują lepszych wyborów. Nie chodzi zatem w tym wypadku o to, by studenci zdobywali kompetencje, które pozwolą im osiagnąć lepszą pozycję na rynku pracy. Chodzi o to, aby inwestować w humanistykę, abyśmy żyli w społeczeństwie obywateli, którzy podejmują świadome wybory.

\section{Emanuel Kulczycki}

Dr hab., prof. UAM; zajmuje się ewaluacją nauki oraz komunikacją naukową. Pracuje w Centrum Studiów nad Polityką Publiczną (Uniwersytet im. Adama Mickiewicza w Poznaniu), gdzie kieruje grupa badawczą Scholarly Communication Research Group. Jest przewodniczącym tzw.Zespołu ds. oceny czasopism oraz członkiem Komitetu Ewaluacji Jednostek Naukowych, Komisji ds. Akredytacji i Rankingów KRASP, a także Krajowej Rady Bibliotecznej. Swoje wyniki publikował m.in. w „Nature”, „Research Evaluation”, ,Journal of Informetrics” i „Scientometrics”. Prowadzi blog „Warsztat badacza”.

Kontakt: emek@amu.edu.pl 